\title{
TRADE OFF THEORY DAN KECEPATAN PENYESUAIAN KE ARAH TARGET LEVERAGE
}

\author{
Dwi Cahyaningdyah ${ }^{1}$ \\ Universitas Airlangga ${ }^{1}$ \\ Email korespodensi: dcahyaningyah@yahoo.com
}

\begin{abstract}
Trade off theory of capital structure predicts that firms have optimal target leverage. However, empirical studies provide evidence that firms' capital structure often deviate from the target because of economic shocks. Therefore firm should make adjustment toward target leverage to maintain optimal trade off between cost and benefit of their financing decision. Understanding adjustment behavior of the firm is key factor to comprehend firms' capital structure dynamic. Nevertheless, asan important issue in corporate finance, speed of adjustment estimation still have several problems caused bias and spurious result. By analysing and synthesizing several studies, this paper revisited the problem and identified several econometric problems of the model used by previous studies. Some solution are provided and direction for future research are proposed.
\end{abstract}

Keywords: trade off theory, speed of adjustment, partial adjustment model, dynamic trade off model

\section{PENDAHULUAN}

Struktur modal masih menjadi topik yang kontroversial dalam corporate finance. Kontroversi teori struktur modal dimulai sejak Modigliani \& Miller (1958) mengembangkan capital structure irrelevance theory. Menurut teori ini, dampak keputusan pendanaan pada nilai perusahaan adalah tidak relevan di bawah kondisi tertentu misalnya tidak ada pajak, tidak ada biaya kebangkrutan dan sebagainya.

Di masa-masa berikutnya, literatur struktur modal telah diperluas oleh banyak teori lain. Tiga teori utama yang paling berpengaruh adalah Pecking Order theory, Trade-off theory, dan Market Timing theory. Asumsi dasar dari ketiga teori struktur modal tersebut adalah bahwa struktur modal adalah relevan untuk nilai perusahaan ketika pajak, biaya transaksi, biaya kebangkrutan dan asimetri informasi dipertimbangkan. Secara lebih khusus, perusahaan memilih antara hutang dan ekuitas sebagai sumber pendanaan berdasar pada faktor spesifik perusahaan (firm-specific factors), misalnya profitabilitas, ukuran perusahaan, tangibility dan lain-lain, dan juga faktor makroekonomi seperti tingkat inflasi, tingkat bunga, pertumbuhan ekonomi.

Trade off theory merupakan pandangan klasik dari teori struktur modal yang menyatakan bahwa perusahaan memiliki optimal target leverage ratio untuk menyeimbangkan risiko kebangkrutan (bankruptcy risk) dan keuntungan pajak (tax benefit) dari penggunaan hutang untuk pendanaan perusahaan (debt financing). Perusahaan akan berusaha untuk menyeimbangkan keuntungan dan biaya yang dihubungkan dengan hutang dengan menjaga rasio leverage pada tingkat target yang optimal tersebut (Baxter, 1967; Jensen and Meckling 1976; Fischer, et al. 1989). Namun secara empiris, seringkali perusahaan menyimpang (terdeviasi) dari tingkat leverage optimal mereka karena adanya kejutan-kejutan ekonomi (economics shock) yang memaksa perusahaan menanggapinya dengan membuat kebijakan struktur modal yang membuat perusahaan bergerak menjauhi tingkat optimal struktur modalnya.

The pecking order model merupakan teori alternatif yang ditawarkan oleh Myers, (1984). Pecking order muncul jika biaya dari menerbitkan sekuritas berisiko menutup biaya dan benefit yang diajukan 


\section{Dwi Cahyaningdyah - Trade Off Theory dan Kecepatan Penyesuaian Ke Arah...}

oleh trade-off model. Biaya untuk menerbitkan sekuritas berisiko menimbulkan pecking order yaitu perusahaan mendanai investasi baru, pertama dengan laba ditahan (retained earning), kemudian dengan hutang yang tidak berisiko (safe debt), kemudian hutang berisiko (risky debt) dan akhirnyadengan outside equity. Secara singkat, (Myers, 1984) menyajikan pecking order model sebagai sebuah teori tentang bagaimana perusahaan mendanai dirinya sendiri dan tentang struktur modal yang dihasilkan dari pendanaan yang dipilih perusahaan sekuen ( pecking order financing).

Sementara Market Timing theory yang dihubungkan dengan struktur modal pertama kali diteliti oleh Baker \& Wurgler (2002). Market timing theory menyatakan bahwa perusahaan melakukan pemilihan waktu yang tepat untuk aktivitas penerbitan (pembelian kembali) sekuritas berdasar periode overvaluation (undervaluation) dari saham mereka. Perusahaan akan lebih memilih untuk menerbitkan ekuitas ketika harga saham mereka dinilai pasar melebihi nilai fundamentalnya (overvaluation) dan memilih untuk membeli kembali saham (repurchasing) atau menerbitkan hutang ketika harga saham mereka dinilai lebih rendah dari nilai fundamentalnya (underpricing).

Kraus \& Litzenberger merupakan yang pertama mengembangkan teori klasikTrade off, yang memprediksi bahwa leverage optimal mencerminkan trade off antara biaya kebangkrutan dan keuntungan pajak dari penggunaan hutang. Trade off theory yang klasik yaitu static trade off theory dibedakan dengan dynamic trade off theory dimana leverage target bervariasi sepanjang waktu berkaitan dengan time-varying determinant.

Menurut Frank \& Goyal(2009) merujuk pada static-trade off theory, keputusan struktur modal harus berdasar pada kharakteristik perusahaan seperti risiko bisnis dan struktur aset. Sehingga menurut trade off theory, perusahaan dengan intangible asset yang besar seharusnya menggunakan sedikit leverage, kerena perusahaan ini seringkali menghadapi biaya kebangkrutan yang tinggi daripada perusahaan dengan tangible asset, yang dapat digunakan sebagai jaminan (collateral).

Menurut Myers (1984), dynamic trade off theory ditandai oleh fakta bahwa perusahaan menetapkan debt-equity target dan secara gradual menyesuaikan struktur modal mereka ke arah target ketika terjadi shock. Beberapa model dinamis awal menganalisis contiuous time models dengan ketidakpastian, pajak, biaya kebangkrutan, dan bebas dari biaya transaksi. Dalam kasus adverse shock, model ini membuat perusahaan tidak dapat melakukan rebalancing struktur modal mereka ke arah debt-equity ratio target tanpa mempertimbangkan biaya transaksi. Tetapi Fischer et al. (1989) bergerak satu langkah lebih jauh dan memperkenalkan biaya kebangkrutan dalam dynamic trade off model mereka. Daripada bereaksi secara cepat pada adverse shock terkait ketiadaan biaya transaksi, perusahaan membiarkan struktur modal mereka menyesuaikan secara gradual (to drift) dalam jangka waktu yang relatif panjang. Perusahaan menunggu untuk rebalancing sepanjang biaya penyesuaian melebihi nilai yang hilang berkaitan dengan struktur modal yang tidak optimal. Perilaku semacam ini diperhitungkan untuk observasi empiris bahwa ada hubungan negatif antara profitabilitas dan leverage. Sebagai contoh, Hovakimian et al. (2001) mengklaim bahwa profitabilitas yang tinggi dihubungkan dengan leverage yang rendah dan juga peluang yang lebih tinggi dari penerbitan debt daripada penerbitan ekuitas. Frank \& Goyal (2009) menganalisis panel data yang besar dan menemukan data menggambarkan rebalancing yang bersifat drift daripada active rebalancing. Hasil ini dapat 
dijelaskan oleh keberadaan biaya transaksi dalam dunia nyata.

Sementara trade off theory menjadi populer di antara banyak akademisi ketika berbicara tentang struktur modal optimal, ada juga perdebatan yang terjadi. Pandangan static trade off theory yang berdasar pada formula tax shield Millers (1977) yang menyatakan bahwa perusahaan seharusnya menekankan pada benefit debt tax shield melawan biaya dari risiko kebangkrutan. Tetapi penelitian empiris muncul yang hasilnya bertentangan dengan ide sentral static trade off theory. Sebagai contoh Graham, (2000) menyatakan bahwa secara paradoksikal perusahaan besar yang likuid dan profitabel dengan distress cost yang rendah menggunakan hutang secara konservatif. Lebih jauh Myers (1993) menyatakan bahwa bukti paling kuat yang bertentangan dengan static trade off theory adalah hubungan terbalik yang kuat antara profitabilitas dan leverage. Baker \& Wurgler (2002) juga menolak pandangan trade off theory yang mengklaim bahwa trade off theory memprediksi bahwa fluktuasi temporer dalam market to book ratio atau variabel lain memiliki efek temporer.

Hackbarthet al. (2007) menyatakan bahwa model trade off yang ada tidak menyediakan guidance untuk struktur hutang perusahaan dan hanya menganalisis jumlah optimal hutang yang seharusnya dimiliki perusahaan. Hart dan Moore (1995) sependapat dengan Hackbarth et al.(2007) dengan mengklaim bahwa trade off theory tidak dapat menjelaskan tipe debt claim dalam prakteknya. Dengan kata lain, trade off model seperti yang dikembangkan oleh Fischer et al., (1989) (1989), Kane et al. (1984), Leland (1994), Strebulaev (2004) dan Titman \& Tsyplakov (2007) gagal untuk menjelaskan struktur hutang.

Merujuk pada relevansi tax shield dan biaya kebangkrutan pada keputusan sturktur modal optimum, Welch (2004) menyatakan bahwa keputusan debt-equity tetap merupakan misteri besar. Sumber utama misteri ini adalah berdasar pada fakta bahwa hampir mustahil untuk mengidentifikasi first order friction yang menyediakan counterbalance untuk tax shield dan sehingga membatasi benefit hutang.

Kontras dengan irrelevant theory Modigliani \& Miller (1958), tujuan trade off theory adalah menunjukkan bahwa keputusan struktur modal perusahaan adalah relevan. Trade off theory menghubungkan dua ketidaksempurnaan pasar yaitu pembayaran pajak dan biaya kebangkrutan dan membawa pandangan yang relatif sederhana bahwa perusahaan seharusnya memilih struktur modal mereka dengan membobot benefit dari pajak hutang dan biaya financial distress. Dengan logika sederhana dan komprehensif tersebut, pandangan ini mendapat banyak dukungan dari akademisi sejak awal munculnya seminal work dari Kraus \& Litzenberger (1973).

Tetapi sejumlah besar penelitian empiris muncul, menunjukkan perusahaan gagal mengikuti ide dasar trade off theory. Intinya adalah bahwa postulate trade off theory bahwa perusahaan adalah subyek untuk struktur modal optimal di mana deviasi dari target hanyalah temporer yang menimbulkan adjustment. Tetapi rasionalitas ini sulit diimplementasikan dalam realita. Jika estimasi tax shield terlihat relatif tidak problematik, penentuan biaya kebangkrutan yang eksak sangat tidak mungkin dalam realitas.

Beberapa hasil empiris kontradiktif dengan trade off theory. Pertama, penelitian empiris menemukan bahwa perusahaan menghadapi peluang pertumbuhan yang besar dan memiliki intangible asset yang besar adalah subyek untuk pendanaan dengan lebih sedikit hutang (less debt financing). Kedua, isu paling mendasar terkait validitas trade off theory adalah temuan empiris hubungan negatif antara profitabilitas dan debt ratio perusahaan. Menurut ide trade off theory, hubungan antara keduanya adalah positif. 


\section{Dwi Cahyaningdyah - Trade Off Theory dan Kecepatan Penyesuaian Ke Arah...}

Profitable firm ditandai dengan biaya kebangkrutan yang rendah dan dapat memperoleh benefit dari tax shield dengan terlibat pada massive debt financing. Tetapi, penelitian empiris kontradiktif dengan rasionalitas tersebut. Secara spesifik, profitable firm cenderung memiliki equity ratio lebih tinggi dibanding non-profitable firm. Yang ketiga, sejarah menunjukkan bahwa perusahaan telah menggunakan leverage jauh sebelum pajak pendapatan perusahaan ada. Konsekuensinya, pajak pendapatan perusahaan yang tidak dapat diperhitungkan untuk struktur perusahaan US tidak banyak mempengaruhi setelah pajak pendapatan perusahaan ada.

Beberapa penulis menyebutkan bahwa trade off theory adalah teori yang paling banyak didiskusikan dan paling berpengaruh dalam literatur struktur modal.Keberadaan target leverage menjadi pembeda di antara ketiga teori tersebut. Di satu sisi, Trade Off Theory menyatakan ada tingkat optimum struktur modal yang menjadi target perusahaan agar dapat menyeimbangkan biaya dan manfaat struktur modal mereka, sementara di sisi lain Pecking Order Theory dan Market Timing Theory secara eksplisit menyatakan bahwa perusahaan tidak memiliki target leverage, sehingga perusahaan tidak berusaha untuk menyesuaikankembali struktur modalnya ke arah target ketika struktur modalnya menyimpang dari target. Dalam Market Timing theory, ketiadaan perilaku targeting ini membuat aktivitas timingyang dilakukan (timing behavior) memiliki dampak terhadap rasio leverage mereka sehingga timing akan menyebabkan perubahan besar dalam leverage untuk perusahaan yang berhasil dalam aktivitas timing mereka.

Flannery \& Rangan, (2006) menemukan bahwa perusahaan memiliki target struktur modal jangka panjang dan perusahaan selalu bergerak (converges) ke arah target. Kecepatan penyesuaiannya tiga kali lebih besar daripada yang diestimasi oleh literatur sehingga perilaku targeting merupakan efek penting dalam struktur modal perusahaan.Ketika ditambahkan variabel market timing dan pecking order pada spesifikasi dasar, tidak ditemukan dukungan untuk kedua teori ini.

Kemajuan yang telah dicapai di area ini adalah menghubungkan dinamika kedalam kerangka statis berdasar intuisi dan argumen bahwa perusahaan seharusnya melakukan penyesuaian secara partial ke arah target leverage mereka sepanjang waktu. Model dinamis menjelaskan observasi empiris terhadap deviasi dari target leverage. Tetapi estimasi empiris terhadap kecepatan penyesuaian (speed of adjustment) ke arah target leverage memberikan hasil yang sangat bervariasi antar studi (misalnya Huang \& Ritter, 2009; Lemmon, et al., 2008) dan secara umum para peneliti memberi argumen bahwa kecepatan penyesuaian empiris tidak cukup cepat untuk memberi dukungan yang meyakinkan pada argumen dynamic trade off (Graham \& Harvey, 2001).

Bukti-bukti untuk trade off theory memberikan hasil yang berbeda-beda. Beberapa penelitian menemukan bahwa perusahaan bergerak relatif cepat ke arah target rasio hutang (misalnya (Flannery \& Rangan, 2006), sementara penelitian lain menyimpulkan bahwa mean reversion terjadi pada snail's pace (pada kecepatan yang sangat lambat) (Fama \& French, 2002). Lebih jauh bagian substansial dari bukti berdasar target adjustment model dikritik oleh Chang \& Dasgupta (2009). Mereka menunjukkan bahwa mungkin menemukan target adjustment behavior bahkan ketika sampel digerakkan melalui simulasi di mana diasumsikan tidak ada target leverage.

Dalam perkembangannya, banyak strategi pengujian perilaku penyesuaian ke arah target (targeting behavior) yang diusulkan yang kemudian memunculkan kritik atas strategi pengujia tersebut terkait kelemahan ekonometri yang terkandung dalam model. Sehingga target adjustment 
behavior (perilaku targeting perusahaan) masih menjadi topik diskusi yang cukup intens dalam literatur struktur modal.

Paper ini melakukan analisis dan review penelitian-penelitian terkini terkait isu kecepatan penyesuaian ke arah leverage target dengan melakukan studi literatur terhadap penelitian-penelitian yang telah dipublikasikan di berbagai jurnal untuk menemukan berbagai masalah termasuk masalah-masalah ekonometri yang masih menjadi perdebatan. Paper ini tidak bertujuan memberikan solusi atas berbagai permasalahan tersebut, tujuan studi ini adalah memberi gambaran terbaru perdebatan di seputar perilaku penyesuaian ke arah target yang dilakukan oleh perusahaan dalam kerangka trade off theory.

\section{HASIL DAN PEMBAHASAN} Kecepatan Penyesuaian $\mathrm{Ke}$ Arah Leverage Target (Speed of Adjustment)

Kecepatan penyesuaian ke arah target struktur modal (Speed of Adjutment/SOA) merupakan variabel yang berkaitan dengan trade-off theory. Trade off theory mendukung keberadaan target leverage, namun perusahaan seringkali terdeviasi dari leverage target karena adanya economic shock yang menyebabkan perusahaan mengambil kebijakan yang memengaruhi struktur modalnya.

Penyesuaian ke arah leverage target adalah perilaku dinamis yang diharapkan oleh teori struktur modal yang mengasumsikan keberadaan leverage target. Penyimpangan dari leverage target adalah kondisi yang mahal dan menuntut tindakan cepat untuk kembali pada target. Perilaku adjustment mencerminkan tiga faktor yaitu leverage target, biaya deviasi dari leverage target dan biaya penyesuaian kearah leverage target (Flannery \& Rangan, 2006).

Menurut (Myers, 1984), dynamic trade off theory ditandai oleh fakta bahwa perusahaan menetapkan debt-equity target dan secara gradual menyesuaikan struktur modal mereka ke arah target ketika terjadi shock. Beberapa model dinamis awal menganalisis contiuous time models dengan ketidakpastian, pajak, biaya kebangkrutan dan bebas dari biaya transaksi. Dalam kasus adverse shock, model ini membuat perusahaan tidak dapat melakukan penyesuaian struktur modal mereka ke arah target debt-equity ratio tanpa mempertimbangkan biaya transaksi. Tetapi Fischer et al.(1989) bergerak satu langkah lebih jauh dan memperkenalkan biaya kebangkrutan dalam dynamic trade off model mereka. Perusahaan tidak bereaksi secara cepat pada adverse shock terkait ketiadaan biaya transaksi, tapi membiarkan struktur modal mereka menyesuaikan secara gradual (to drift) dalam jangka waktu yang relatif panjang.

Beberapa penelitian mengidentifikasi determinan yang mempengaruhi kecepatan penyesuaian ke arah target yaitu kharakteristik spesifik perusahaan (firm specific factors) antara lain profitabilitas, ukuran perusahaan, asset tangibility, peluang pertumbuhan, financial constraint dan deviasi dari target; faktor makroekonomi, kondisi ekonomi dan siklus bisnis (contoh Korajczyk \& Levy, 2003).

Dalam kondisi terdeviasi dari target perusahaan memiliki pilihan untuk kembali ke target atau bertahan pada posisi yang menyimpang dari target. Perusahaan akan kembali ke target jika biaya penyesuaian ke arah target lebih kecil daripada biaya deviasi dari target. Sehingga perusahaan melakukan penyesuaian (adjustment) ke arah target pada kecepatan penyesuaian tertentu.

Sehingga beberapa penelitian menyatakan bahwa kecepatan penyesuaian antar perusahaan berbeda berdasar kondisi spesifik perusahaan tersebut.Perilaku adjustment tidak identik untuk semua perusahaan Clark, Francis, \& Hasan, 2009; Flannery \& Rangan, 2006; Lemmon, Roberts, \& Zender, 2008). Heterogenitas kecepatan penyesuaian antar perusahaan ini ditentukan oleh trade-off antara biaya dan benefit, dan deviasi leverage mula- 


\section{Dwi Cahyaningdyah - Trade Off Theory dan Kecepatan Penyesuaian Ke Arah...}

mula menjadi faktor yang menentukan heterogenitas tersebut (Mukherjee \& Wang, 2013).

Kecepatan penyesuaian ke arah target struktur modal tergantung pada biaya deviasi dari leverage target dan biaya penyesuaian ke arah target. Jarak leverage perusahaan dari target dan apakah perusahaan overleverage atau underleverage merupakan aspek yang berpengaruh pada kecepatan penyesuaian ke arah leverage target (Clark et al., 2009, 2009; Lemmon, Roberts, and Zender, 2008). Perusahaan yang memiliki leverage dekat dengan target akan memiliki tingkat adjustment yang lebih lambat daripada perusahaan yang memiliki leverage jauh dari target karena biaya deviasinya lebih rendah. Perusahaan yang overleverage memiliki SOA lebih tinggi dibanding dengan perusahaan yang underleverage sebagai hasil dari biaya deviasi yang lebih tinggi (Dang, Garrett, \& Nguyen, 2010). Mukherjee \& Wang (2013) mengkonfirmasi adanya sensitivitas SOA terhadap deviasi leverage dan sensitivitas ini adalah positif. Dengan kata lain, SOA secara robust dan secara positif berhubungan dengan jarak dari target leverage.

Faulkender et al. (2010) menemukan bahwa sensitivitas SOA terhadap deviasi leverage tergantung pada apakah struktur modal persahaan dibawah atau di atas target. SOA untuk perusahaan yang memiliki leverage di atas target (overlevered firm) diestimasi akan meningkat secara lebih cepat daripada SOA untuk perusahaan yang memiliki leverage di bawah target (underlevered firm).

Byoun (2008) meneliti pengaruh financial constraint perusahaan dan pengaruhnya pada kecepatan penyesuaian ke arah leverage target dan menemukan bahwa perusahaan membuat penyesuaian ke arah target leverage secara signifikan ketika mereka berada di atas target leverage (above-target debt) dengan financial surplus. Perusahaan akan menghadapi biaya penyesuaian yang lebih rendah ketika mengurangi hutang dari posisi di atas target daripada menerbitkan debt ketika perusahaan berada di bawah target (below-target debt). Biaya untuk menjaga above target debt lebih tinggi daripada menjaga below target debt.

Temuan Byoun (2008) didukung oleh Dang et al. (2010) yang menyatakan bahwa perusahaan yang over-levered memiliki lebih banyak alasan secara relatif untuk mengkhawatirkan deviasi dari target leverage, sementara perusahaan yang under-levered cenderung lebih rileks. Sementara perusahaan dengan kondisi financing deficit bergerak ke arah target leverage dengan lebih cepat dibanding perusahaan yang berada dalam kondisi financing surplus, karena perusahaan dengan financing deficit memiliki lebih banyak insentif untuk masuk ke pasar modal untuk menutup gap keuangan mereka dibandingkan perusahaan yang ada dalam kondisi financing surplus.

\section{Beberapa Masalah Ekonometri Terkait Estimasi Kecepatan Penyesuaian Ke Arah Leverage Target}

Pengujian perilaku penyesuaian struktur modal terbagi dalam dua kategori yaitu yang pertama menggunakan qualitative dependent variable model, temuannya adalah probabilitas menerbitkan hutang daripada ekuitas atau membeli kembali ekuitas daripada hutang menurun seiring dengan tingkat di mana rasio leverage perusahaan melebihi target leverage perusahaan. Kelompok pengujian kedua adalah dengan cara menguji kecepatan rata-rata dimana perusahaan menyesuaikan ke arah target leverage menggunakan partial adjustment regression model.

Beberapa masalah terkait metode estimasi kecepatan penyesuaian ke arah target leverage diidentifikasi dalam beberapa penelitian. Hovakimian \& $\mathrm{Li}$ (2012) melakukan pengujian untuk mengetahui apakah partial adjustment model dan SOA yang dihasilkan oleh model tersebut merupakan alat yang 
berguna dalam penelitian struktur modal. Hasil penelitian ini mempertanyakan interpretasi standar dari partial-adjustment coeficient sebagai ukuran ekonomi yang bermakna dari pentingnya target leverage karena deviasi dari standard target adjustment behavior yang diasumsikan oleh partial adjustment model adalah relatif umum dan mungkin sulit menginterpretasikan SOA sebagai bukti perilaku penyesuaian kembali ke arah target (rebalancing) tertentu.

Standard partial adjustment model mengasumsikan bahwa semua perusahaan dalam sampel menyesuaikan pada kecepatan rata-rata yang sama. Kelemahan ini diperbaiki dalam dynamic capital structure theory yang memprediksi heterogenitas kecepatan penyesuaian antar perusahaan karena adanya kharakteristik unik dari masing-masing perusahaan yang menyebabkan biaya penyesuaian yang berbeda antar perusahaan ( $\mathrm{R}$ Elsas \& Florysiak, 2011). Asumsi lain yang tidak rasional adalah asumsi tentang kesamaan ratio leverage optimal untuk semua perusahaan, sementara masing-masing perusahaan memiliki kharakteristik spesifik yang berbeda-beda yang akan berpengaruh pada perbedaan target leveragel leverage optimal antar perusahaan.

Titman \& Tsyplakov (2007) menyatakan target debt ratio yang mungkin saja berubah-ubah karena adanya economic shock yang menggerakkan perusahaan menjauhi target debt ratio dan mungkin juga menyebabkan target debt ratio bergerak sepanjang waktu, ini akan menyebabkan analisis SOA menjadi lebih rumit.

Menurut Bontempi et al. (2015) pemahaman dinamika ratio leverage merupakan inti penelitian empiris tentang struktur modal. Dinamika tersebut bisa sangat berbeda di bawah alternatif model teoritis berbeda. Pilar dari hampir semua aplikasi empiris adalah asumsi poolability dan stationarity yang dimotivasi oleh kebutuhan simplicity dan treatability model daripada berdasar pada landasan empiris. Bontempi et al. (2015) memberikan bukti yang robust dari nonstationarity rasio leverage pada sejumlah besar saham di US dan bukti untuk heterogenitas yang kuat dalam kecepatan penyesuai perusahaan ke arah target leverage. Hasil ini kemudian mendorong riset empiris tentang dinamika rasio hutang dengan lebih bertumpu pada konsep heterogenitas tingkat persistensi leverage. Sehingga Bontempi et al. (2015) memperkenalkan pendekatan baru dan sederhana untuk melihat dinamika rasio leverage perusahaan berdasar fakta bahwa perusahaan adalah heterogen dalam SOA karena perusahaan tersebut menghadapi constraint yang berbeda dan bahwa fluktuasi ratio leverage aktual sepanjang waktu sangat persisten. Di sisi lain, secara kontras Lemmon et al. (2008) mengemukakan bahwa leverage perusahaan adalah stabil dan digerakkan oleh time-invariant determinantyaitu determinan yang relatif tidak bervariasi sepanjang waktu.

Beberapa penelitian juga mempertanyakan makna dari estimasi kecepatan penyesuaian. Chang dan Dasgupta (2009) menyatakan bahwa pengujian perilaku targeting tidak dapat mengakomodir mechanical mean reversion dimana leverage cenderung turun ketika mendekati 1 dan cenderung naik ketika mendekati 0 . Menurut Hovakimian and Li (2011) mean reversion tersebut terjadi bersumber pada metode tradisional yang mengandung bias karena tidak memperhitungkan sifat rasio leverage yang merupakan pecahan sehingga rasio leverage akan bounded diantara nilai 0 dan 1 . Lebih jauh Iliev dan Welch (2011) menyatakan bahwa estimator SOA dalam partial adjustment model gagal memperhitungkan boundedness dari rasio leverage yaitu sifat rasio leverage yang bounded antara 0 dan 1 (fractional) sehingga menimbulkan mechanical mean reversion dari leverage 


\section{Dwi Cahyaningdyah - Trade Off Theory dan Kecepatan Penyesuaian Ke Arah...}

(Chen dan Zao, 2007; (Chang \& Dasgupta, 2011).

Elsas and Florysiak (2015) menyatakan bahwa estimasi regresi dimana variabel terikatnya adalah pecahan (fractional) yang nilainya antara 0 dan 1 , mensyaratkan metode ekonometri yang memperhitungkan fractionality ini. Sementara estimator standar seperti Ordinary Least Square (OLS) mengasumsikan variabel terikat dapat mengambil setiap angka riil negatif atau positif manapun. Pengabaian fraksionalitas ini akan menyebabkan estimasi dan inferensi yang bias dan akan menyebabkan kesalahan kesimpulan. Elsas dan Florysiak (2015) mengusulkan estimator baru yang dapat menghasilkan SOA yang tidak bias untuk standard partial adjustment model dengan adanya fractional dependent variable. Estimator ini tidak bias dan konsisten dalam konteks unbalance dynamic panel data dengan fractional dependent variable (DPF estimator) dan memperhitungkan fixed effect (yaitu unobserved, time invariant firm heterogeneity). Estimator ini dapat digunakan di area corporate finance dimana partial adjustment model digunakan.

Hovakimian dan Li (2012) juga mempertanyakan makna estimasi kecepatan penyesuaian, mereka menyatakan bahwa bahkan perusahaan yang berada padarebalancing pointyaitu titik dimana perusahaan harus melaukan penyesuaian ke arah target dan biaya penyesuaian yang relatif rendah memiliki estimasi SOA yang jauh lebih rendah dari 1 yang menunjukkan bahwa perusahaan tidak melakukan penyesuaian ke arah target secara penuh. Sementara Graham dan Leary (2011) menyatakan bahwa kecuali SOA 1 atau 0, estimasi SOA tidak dapat mengidentifikasi motivasi dibalik keputusan pendanaan perusahaan. Sehingga para peneliti tersebut mempertanyakan informasi apa sesungguhnya yang terkandung dalam SOA.
Hovakimian dan Li (2011) juga menyatakan bahwa partial adjustment model dapat menggerakkan estimasi signifikan yang lancung (spurious) yang konsisten dengan hipotesis bahwa perusahaan memiliki target debt ratio yang secara periodik disesuaikan. Regresi fullsample fixed effect model dari rasio leverage target akan menghasilkan bias yang parah terkait target adjustment hypothesis. Sehingga Hovakimian dan $\mathrm{Li}$ (2011) menyatakan perlu dilakukan modifikasi untuk metodologi standar sehingga bias dapat dieliminasi.

Karena banyaknya kritik ekonomertik atas penelitian terkini yang mengestimasi kecepatan penyesuaian untuk menguji mean reversion rasio hutang perusahaan ke arah target rasio hutang, Hovakimian \& Li (2012) menyatakan bahwa kecepatan penyesuaian mungkin bukan merupakan ukuran yang bermakna secara ekonomi untuk perilaku perusahaan mengikuti target (target-following behavior), deviasi dari target merupakan hal yang umum dijumpai dan perilaku penyesuaian ke arah target seringkali tidak terjadi, karena banyak perusahaan yang semula berada di atas target (above target) secara simpel menjadi di bawah target (below target) sebagai hasil dari corporate financing yang mereka lakukan.

Hasil mereka juga dipengaruhi pembalikan rasio hutang ke arah rata-rata yang terjadi secara mekanis (mechanical mean reversion) berkaitan dengan faktor seperti inter-temporer pattern untuk kebutuhan pendanaan eksternal Shyamsunder \& Myers (1999) dan rasio hutang yang bounded antara 0 dan 1 . Chen \& Zhao(2007) dan Chang \& Dasgupta (2009) menunjukkan bahwa hasil partialadjustment, dynamic trade off model dapat diperoleh bahkan jika perusahaan mengikuti random financing behavior yang independent terhadap target debt ratio. Mereka berargumen bahwa menggunakan leverage ratio dalam pengujian ini mungkin misleading dan bahwa pengujian dimasa depan seharusnya 
fokus pada aktivitas issurance perusahaan untuk menolak alternatif, non-target behavior secara berhasil.

Terkait isu ini, penelitian di area struktur modal harus dapat mengembangkan strategi pengujian untuk menguji apakah target behavior perusahaan yaitu intentional target behavior dapat dibedakan dari random financing behavior. Dalam strategi pengujian ini, target behavior tidak disimpulkan dari pergerakan rasio hutang semata-mata, tapi penelitian ini seharusnya fokus pada pilihan financing perusahaan untuk menarik inferensi. Karena pergerakan rasio hutang dapat menjadi misleading, maka dipertimbangkan pilihan financing sebagai tindakan yang disadari (consiuos attempts) untuk menggerakkan rasio hutang ke arah intended target level (Chauhan \& Huseynov, (2016).

\section{KESIMPULAN}

Pemahaman dinamika ratio leverage merupakan inti penelitian empiris terkait struktur modal. Kecepatan penyesuaian ke arah leverage merupakan salah satu indikator untuk mengetahui bagaimana dinamika ratio leverage perusahaan. Sifat dinamis leverage target yang berubah dari waktu ke waktu dan beberapa sifat ratio leverage lain misalnya nilai rasio yang merupakan pecahan, membuat penelitian struktur modal dalam konteks dinamis ini menjadi rumit. Ada banyak kelemahan metodologi yang telah diidentifikasi oleh para peneliti dan masih terus diperdebatkan bagaimana mengatasi kelemahan tersebut sehingga hasil penelitian menjadi tidak bias.

Masih banyak celah yang dapat diangkat dalam penelitian-penelitian selanjutnya terkait isu struktur modal perusahaan.Karena metode-metode baru yang diusulkan pun masih perlu dimurnikan supaya kita yakin bahwa metode dan model baru tersebut benarbenar merupakan alat analisis yang paling tepat. Masalah-masalah seperti fraksionalitas rasio leverage, heterogenitas
SOA, penyesuaian yang tidak simetris, dan pengaruh unobservable variable yang sifatnya time-invatiant serta isu terkait intentional target behavior tetap akan menjadi isu menarik dalam ranah penelitian keputusan struktur modal.

\section{REFERENSI}

Baker, M., \& Wurgler, J. (2002). Market Timing and Capital Structure. The Journal of FInance, LVII(1), 1-32.

Baxter, N. D. (1967). Leverage, Risk of Ruin and Cost of Capital. The Journal of Finance, 22(3), 395-403.

Bontempi, M. E., Bottazzi, L., \& Golinelli, R. (2015). Dynamic corporate capital structure behavior : empirical assessment in the light of heterogeneity and non stationarity. Working Paper.

Byoun, S. (2008). How and When Do Firms Adjust Their Capital Structures toward Targets? Journal of Finance, LXIII(6), 3069-3096.

Chang, X., \& Dasgupta, S. (2009). Target Behavior and Financing: How Conclusive Is the Evidence? The Journal of Finance, LXIV(4), 17671796.

Chang, X., \& Dasgupta, S. (2011). Monte Carlo simulations and capital structure research. International Review of

Finance, 11(1), 19-55. https://doi.org/10.1111/j.14682443.2011.01126.x

Chauhan, G. S., \& Huseynov, F. (2016). Corporate financing and target behavior: New tests and evidence. Journal of Corporate Finance. https://doi.org/10.1016/j.jcorpfin.2016. 10.013

Chen, L., \& Zhao, X. (2007). Mechanical mean reversion of leverage ratios. Economics Letters, 95, 223-229. https://doi.org/10.1016/j.econlet.2006.1 0.008

Clark, B., Francis, B., \& Hasan, I. (2009). Do firms adjust toward target capital structures? Some international evidence. SSRN Electronic Journal, (December 2007). 
Dang, V., Garrett, I., \& Nguyen, C. (2010). Asymmetric Partial Adjustment towards Target Leverage : International Evidence. Unpublish Manuscript, University of Manchester.

Elsas, R., \& Florysiak, D. (2011). Heterogeneity in the Speed of Adjustment toward Target. International Review of Finance, 11(2), 181-211. https://doi.org/10.1111/j.14682443.2011.01130.x

Elsas, R., \& Florysiak, D. (2015). Dynamic Capital Structure Adjustment and the Impact of Fractional Dependent Variables. Journal of Financial and Quantitative Analysis, 50(5), 11051133. https://doi.org/10.1017/S002210901500 0496

Fama, E. F., \& French, K. R. (2002). Testing Trade-Off and Pecking Order Predictions about Dividends and Debt Testing Trade-Off and Pecking Order Predictions About Dividends and Debt. The Review of Financial Studies, 15(1), 1-33.

Faulkender, M., Flannery, M. J., Hankins, K. W., \& Smith, J. M. (2010). Cash Flows and Leverage Adjustments. SSRN Electronic Journal.

Fischer, E., Heinkel, R., \& Zechner, J. (1989). Dynamic Capital Structure Choice : Theory and Tests. The Journal of Finance, XLIV(1), 19-40.

Flannery, M. J., \& Rangan, K. P. (2006). Partial adjustment toward target capital structures. Journal of Financial Economics, 79, 469-506. https://doi.org/10.1016/j.jfineco.2005.0 3.004

Frank, M. Z., \& Goyal, V. K. (2009). Capital Structure Decisions : Which Factors Are Reliably Important? Financial Management, (Spring), 1-37.

Graham, J. R. (2000). How Big Are the Tax Benefits of Debt? The Journal of Finance, LV(5), 1901-1941.

Graham, J. R., \& Harvey, C. R. (2001). The theory and practice of corporate finance: Evidence from the field.

Journal of Financial Economics, 60(23), 187-243.

https://doi.org/10.1016/S0304405X(01)00044-7

Graham, J. R., \& Leary, M. T. (2011). A Review of Empirical Capital Structure Research and Directions for the Future. Annu. Rev. Financ. Econ, 3(November), 309-45. https://doi.org/10.1146/annurevfinancial-102710-144821

Hackbarth, D., Hennessy, C. A., \& Leland, H. E. (2007). Can the Trade-off Theory Explain Debt Structure? The Review of Financial Studies, 20(5), 1389-1428. https://doi.org/10.1093/rfs/hhl047

Hovakimian, A., \& Li, G. (2011). In search of conclusive evidence : How to test for adjustment to target capital structure. Journal of Corporate Finance, 17(1), 33-44. https://doi.org/10.1016/j.jcorpfin.2010. 07.004

Hovakimian, A., \& Li, G. (2012). Is the Partial Adjustment Model a Useful Tool for Capital Structure Research ? *. Review of Finance, 16(September), 733-754. https://doi.org/10.1093/rof/rfq020

Hovakimian, A., Opler, T., \& Titman, S. (2001). The Debt-Equity Choice. The Journal of Financial and Quantitative Analysis, 36(1), 1-24.

Huang, R., \& Ritter, J. R. (2009). Theories of Capital Structure and Testing of the Speed Adjustment Estimating. The Journal of Financial and Quantitative Analysis, 44(2), 237-271. https://doi.org/10.1017/S002210900909 0152

Jensen, C., \& Meckling, H. (1976). Theory of The Firm : Managerial Behavior. Agency Cost and Ownership Structure. Journal of Financial Economics, 3, 305-360.

Korajczyk, R. A., \& Levy, A. (2003). Capital structure choice : macroeconomic conditions and financial constraints \$. Journal of 
Financial Economics, 68, 75-109.

Kraus, A., \& Litzenberger, R. H. (1973). A

State-Preference Model of Optimal

Financial Leverage. The Journal of

Finance, 28(4), 911-922.

Lemmon, M. L., Roberts, M. R., \& Zender, J. F. (2008). Back to the Beginning : Persistence and the CrossSection of Corporate Capital Structure. The Journal of Finance, LXIII(4), 1575-1608.

Modigliani, F., \& Miller, M. H. (1958).

The Cost of Capital, Corporate Finance and The Theory of Investment. The American Economic Review, 48(3), 261-297.

Mukherjee, T., \& Wang, W. (2013). Capital Structure Deviation and Speed of. The Financial Review, 48, 597-615.

Myers, S. C. (1984). The Capital Structure Puzzle. The Journal of Finance, 39(3), 575-592.

Shyam-sunder, L., \& Myers, S. C. (1999). Testing static tradeoff against pecking order models of capital structure.

Journal of Financial Economics, 51, 219-244.

Titman, S., \& Tsyplakov, S. (2007). A Dynamic Model of Optimal Capital Structure *. Review of Finance, 11(June), 401-451.

https://doi.org/10.1093/rof/rfm017 